\title{
DIVERSITY OF THE DITERPENES IN THE LEAVES OF Xylopia laevigata (Annonaceae) AND THEIR CYTOTOXICITIES
}

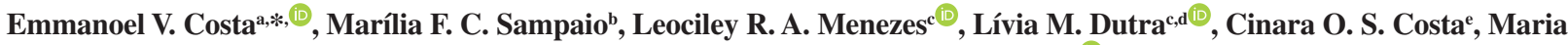
Lúcia B. Pinheiro ${ }^{a}$, Felipe M. A. da Silva ${ }^{a}$, Milena B. P. Soares ${ }^{\mathrm{e}, \mathrm{f}}$, Daniel P. Bezerra ${ }^{\mathrm{e}}$, Andersson Barison ${ }^{\mathrm{c}}$ and Hector H. F. Koolen" ${ }^{\text {(®) }}$

aDepartamento de Química, Universidade Federal do Amazonas, 69080-900 Manaus - AM, Brasil

'Departamento de Química, Universidade Federal de Sergipe, 49100-000 São Cristóvão - SE, Brasil

'Centro de RMN, Universidade Federal do Paraná, Centro Politécnico, 81531-990 Curitiba - PR, Brasil

${ }^{d}$ Núcleo de Estudos e Pesquisas de Plantas Medicinais, Universidade Federal do Vale do São Francisco, 56304-205 Petrolina - PE, Brasil

'Instituto Gonçalo Moniz, Fundação Oswaldo Cruz, 40296-710 Salvador - BA, Brasil

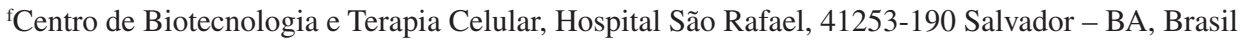

${ }^{g}$ Grupo de Pesquisa em Metabolômica e Espectrometria de Massas, Universidade do Estado do Amazonas, 69065-001 Manaus - AM, Brasil

Recebido em 02/10/2019; aceito em 14/01/2020; publicado na web em 31/03/2020

\begin{abstract}
The phytochemical investigation of the hexane extract which was obtained from the leaves of Xylopia laevigata (Annonaceae) produced six terpenes. Among these, five diterpenes named abieta-7,13-dien-3-one, ent-7 $\beta$-acetoxy-16 $\beta$-hydroxy-kaurane, 4-epi-cupressic acid, powerol, and labdorffianic acid B, and one oxygenated sesquiterpene, spathulenol. This is the first time these isolated diterpenes from $X$. laevigata have been described. The different structures belong to the abietane, kaurane, and labdane diterpenoids, and are indicative of the chemical diversity found in $X$. laevigata. Moreover, the diterpene ent-7 $\beta$-acetoxy-16ß-hydroxykaurane is reported herein for the first time as a natural product, and 4-epi-cupressic acid, powerol, and labdorffianic acid B are reported for the first time in the Annonaceae family. The structures of the isolated compounds were established by extensive analyses using 1D and 2D NMR spectroscopy in combination with MS. The cytotoxic activities of compounds abieta-7,13-dien-3-one, spathulenol, 4-epi-cupressic acid, and powerol were evaluated against tumor and non-tumor cell lines, in which spathulenol was found to be the most active, mainly against $\mathrm{K} 562$ with an $\mathrm{IC}_{50}$ value of $17.20 \mu \mathrm{mol} \mathrm{\textrm {L } ^ { - 1 }}$.
\end{abstract}

Keywords: Annonaceae, Xylopia laevigata; diterpenes; cytotoxic activity.

\section{INTRODUCTION}

The genus Xylopia belongs to the Annonaceae family and comprises approximately 160 species of aromatic shrubs and trees, from which 40 can be found in South America, mainly in the Brazilian cerrado. ${ }^{1,2}$ Several species are used as spices, and as natural medicines for the treatment of skin infections and fever, and also as antiemetic, digestive, and appetite enhancing agents. ${ }^{3,4}$ Previous phytochemical investigations of Xylopia spp. highlighted the presence of terpenoids, ${ }^{5,6}$ flavonoids,,${ }^{5,7}$ and alkaloids. ${ }^{8}$ Some of the isolated compounds from this genus exhibit pharmacological activities, such as antifungal, ${ }^{6,7}$ antioxidant, ${ }^{3,8}$ antileishmanial, ${ }^{9}$ cytotoxic, ${ }^{5,10}$ anti-inflammatory, ${ }^{5,11}$ antinociceptive, ${ }^{5,11}$ acaricidal, ${ }^{12}$ and insecticidal activities. ${ }^{6,13}$

The relevant literature indicates 160 known species of this genus, ${ }^{14}$ and, approximately $20 \%$ ( 30 species $)$ have had previous chemical/pharmacological studies carried out, which reinforces the importance of new studies regarding the species of Xylopia. In this sense, Xylopia laevigata (Mart.) R.E. Fries is a small tree which is endemic to Brazil, popularly known as 'meiú' and 'pindaíba', and is found in the Northeastern and Southeastern regions. ${ }^{1,15}$ In the state of Sergipe, it is found in the last remaining fragments of the Atlantic forest near the coast. ${ }^{15}$ In local folk medicine, leaves and flowers are used in the treatment of painful disorders, inflammatory conditions and, in some cases, heart disease. ${ }^{4}$

*e-mail: emmanoelvc@gmail.com
The essential oils of the leaves of $X$. laevigata are composed mainly of bicyclogermacrene, $\alpha$-cadinene, $(E)$-caryophyllene, $\delta$-copaene, germacrene $\mathrm{D}$, and $\gamma$-muurolene..$^{5,16-18}$ On the other hand, the essential oil composition of the fresh fruits included $\alpha$-pinene, $\beta$-pinene and limonene as major compounds. ${ }^{19}$ Besides, the existing chemical knowledge, biological activities have been recorded for this essential oil; these being antioxidant, ${ }^{4}$ antibacterial, ${ }^{16}$ antifungal, ${ }^{16}$ antinociceptive, ${ }^{16}$ anti-inflammatory, ${ }^{16}$ cytotoxic, ${ }^{4,20}$ larvicidal, ${ }^{16}$ trypanocidal, ${ }^{17}$ and mutagenic ${ }^{20}$ activities.

Furthermore, previous investigations regarding this species have described the identification of ent-kaurane diterpenes, ${ }^{6}$ such as ent-kaur-16-en-19-oic acid, 4-epi-kaurenic acid, ent-16ß-hydroxy17-acetoxy-kauran-19-al, ent-3ß-hydroxykaur-16-en-19-oic acid, and ent-16 $\beta, 17$-dihydroxy- kauran-19-oic acid, as well as spathulenol and a mixture of $\beta$-sitosterol, stigmasterol, and campesterol. ${ }^{6}$ Among them, ent-3 $\beta$-hydroxykaur-16-en-19-oic acid demonstrated potent larvicidal activity against Aedes aegypti larvae and antifungal activity against Candida glabrata and Candida dubliniensis. ${ }^{6}$ Moreover, alkaloids have been identified from leaf and stem extracts of this plant, and were mainly aporphines, oxoaporphines, tetrahydroprotoberberines, and benzylisoquinolines. ${ }^{21,22}$ Among them, lanuginosine, (+)-xylopine, and (+)-norglaucine displayed high cytotoxic activities. ${ }^{22,23}$

In our continuous search for new bioactive natural products from Annonaceae that possess cytotoxic potential, this study aimed to investigate the phytochemical and pharmacological properties of the leaves of X. laevigata. In this report six compounds were isolated and identified. These were five diterpenes and one sesquiterpene, all from 
the leaf hexane extract of $X$. laevigata. In addition, the cytotoxicity of the isolated compounds was assessed against B16-F10, HepG2, K562, and HL-60 tumor cell lines by the Alamar blue assay.

\section{EXPERIMENTAL}

\section{General experimental procedures}

Optical rotations in $\mathrm{CHCl}_{3}$ were recorded with a Jasco P-2000 polarimeter at $589 \mathrm{~nm}$. GC-MS analyses were performed with a Shimadzu QP5050A GC-MS system fitted with a J \& W Scientific DB-5MS (5\%-phenyl-95\%-methylpolysiloxane) fused capillary column $(30 \mathrm{~m} \times 0.25 \mathrm{~mm} \times 0.25 \mu \mathrm{m}$ of film thickness). MS analyses from the GC-MS were recorded at $70 \mathrm{eV}$ with a scan interval of $0.5 \mathrm{~s}$ and the fragments were detected in the $m / z, 40-500 \mathrm{Da}$ range. Low-Resolution Mass Spectra (LRMS) analyses were performed on an Waters TQD mass spectrometer equipped with an ESI source which was operating in the negative ion mode. High-Resolution Electrospray Ionization Mass Spectrometry (HRESIMS) were performed using a Bruker UltrOTOF-Q mass spectrometer. 1D and 2D NMR data were acquired at $303 \mathrm{~K}$ in $\mathrm{CDCl}_{3}$ on a Bruker Avance III $600 \mathrm{NMR}$ spectrometer, operating at $14.1 \mathrm{Tesla}$, and ${ }^{1} \mathrm{H}$ and ${ }^{13} \mathrm{C}$ at 600.13 and $150.61 \mathrm{MHz}$ were observed, respectively. The spectrometer was equipped with a $5 \mathrm{~mm}$, inverse detection, four channel $\left({ }^{1} \mathrm{H}\right.$, ${ }^{13} \mathrm{C},{ }^{15} \mathrm{~N}$, and ${ }^{31} \mathrm{P}$ ) probe with $z$-gradient. One-bond and long-range ${ }^{1} \mathrm{H}-{ }^{13} \mathrm{C}$ correlations from HSQC and HMBC NMR experiments were optimized for average coupling constants ${ }^{1} J_{(\mathrm{H}, \mathrm{C})}$ and ${ }^{\mathrm{LR}} J_{(\mathrm{H}, \mathrm{C})}$ of 140 and $8 \mathrm{~Hz}$, respectively. ${ }^{1} \mathrm{H}$ and ${ }^{13} \mathrm{C}$ NMR chemical shifts were given in ppm related to the TMS signal at $0.00 \mathrm{ppm}$ as the internal reference, and the coupling constants $(J)$ expressed in Hz. Silica gel 60 (70-230 mesh) was used for column chromatography, while silica gel $60 \mathrm{~F}_{254}$ was used for analytical $(0.25 \mathrm{~mm})$, and preparative $(1.00 \mathrm{~mm})$ TLC. Compounds were visualized by exposure to $\mathrm{UV}_{254 / 365}$ light, spraying of $p$-anisaldehyde reagent, and followed by heating on a hot plate.

\section{Botanical material}

Leaves of X. laevigata (SISGEN Register ACAAA36) were collected in Serra de Itabaiana (coordinates: $10^{\circ} 44^{\prime} 53$ ' S, $37^{\circ} 20^{\prime} 21^{\prime \prime} \mathrm{W}$ ), Itabaiana, Sergipe state, Brazil, in March, 2010. The identification was confirmed by Dr. A. P. do N. Prata from the Departamento de Biologia from Universidade Federal de Sergipe. A specimen voucher (\#15440) was deposited in the herbarium of the institution. The Chico Mendes Institute for Biodiversity Conservation, which belongs to the Brazilian Ministry of the Environment, provided an authorization for the sample collection (\#25637-1). This study was also performed according to the special authorization given for access to genetic resources in Brazil \#010240/2013-6, which was issued by $\mathrm{CNPq} / \mathrm{MCTI}$.

\section{Extraction and isolation}

Leaves of $X$. laevigata were dried in an air circulating oven at approximately $40{ }^{\circ} \mathrm{C}$ for $72 \mathrm{~h}$, and subsequently pulverized in a four-knife mill grinder (Marconi) to obtain the powdered material (750.0 g). Then, an exhaustive maceration with hexane $\left(5 \times 3 \mathrm{~L}, 25^{\circ} \mathrm{C}\right)$ followed by $\mathrm{MeOH}\left(5 \times 3 \mathrm{~L}, 25^{\circ} \mathrm{C}\right)$. The extractive solutions obtained were concentrated in a rotary evaporator (Fisatom) at reduced pressure $\left(40-50^{\circ} \mathrm{C}\right)$ in order to yield the hexane $(54.3 \mathrm{~g})$ and $\mathrm{MeOH}(191.1 \mathrm{~g})$ extracts. The hexane extract presented a crystalline appearance after being dried. Subsequently, part $(5.0 \mathrm{~g})$ of the hexane extract was subjected to silica gel column chromatography $(\mathrm{CC})$ which was eluted with gradients constituted of hexane, $\mathrm{CH}_{2} \mathrm{Cl}_{2}$, EtOAc, and $\mathrm{MeOH}$ mixtures in ascending order of polarity, which yielded 230 fractions. After TLC evaluation using a mixture of hexane-EtOAc in the proportions of 95:05, 90:10, 80:20, and 70:30 as the eluent system, the similar samples were pooled to give 20 groups (G1 to $\mathrm{G} 20$ ).

Group $\mathrm{G} 7\left(319.0 \mathrm{mg}\right.$ ) from $\mathrm{CC}$ eluted with hexane- $\mathrm{CH}_{2} \mathrm{Cl}_{2}$ $(10: 90 \mathrm{v} / \mathrm{v})$ and $\mathrm{CH}_{2} \mathrm{Cl}_{2}(100 \%)$ was submitted to a new silica gel $\mathrm{CC}$ eluted with hexane-EtOAc (100:0 to 50:50, $v / v$ ) and yielded 17 subfractions pooled into 8 subgroups (G7.1 to G7.8). Subgroup G7.2 (87.6 mg) from CC eluted with hexane-EtOAc $(97: 03, v / v)$ was submitted to a preparative TLC eluted with hexane-EtOAc (95:05, $v / v$, three elutions) and yielded $1(45.1 \mathrm{mg})$.

Group G9 (562.0 mg) from CC eluted with $\mathrm{CH}_{2} \mathrm{Cl}_{2}$-EtOAc (95:05 and 90:10, $v / v$, respectively) was subjected to a silica gel $\mathrm{CC}$ eluted with hexane-EtOAc (100:0 to 30:70, $v / v)$ and EtOAc-MeOH (100:0 to $20: 80, v / v)$ and yielded 28 subfractions ( $25 \mathrm{~mL}$ each) that were subsequently pooled into 14 groups (G9.1 to G9.14), according to TLC analysis. G9.6 (37.4 mg) from CC eluted with hexane-EtOAc $(95: 05, v / v)$ was submitted to a preparative TLC eluted with hexaneEtOAc (90:10, $v / v$, four elutions) and yielded 2 (16.1 mg).

Group G12 (700.0 mg) from CC eluted with $\mathrm{CH}_{2} \mathrm{Cl}_{2}$-EtOAc $(90: 10, v / v)$ was submitted to another new silica gel $\mathrm{CC}$ eluted with hexane-EtOAc (100:0 to 50:50, v/v) followed by EtOAc-MeOH (100:0 to $20: 80, v / v)$ and yielded 44 subfractions $(25 \mathrm{~mL}$ each) that were pooled into 11 subgroups (G12.1 to G12.11) according to TLC analysis. Subgroup G12.7 (60.0 mg) from CC eluted with hexaneEtOAc 70:30 $v / v$ was submitted to a preparative TLC eluted with hexane-EtOAc (80:20, $v / v$, four elutions) and yielded 3 (4.4 mg).

Group G14 (282.0 mg) from CC eluted with $\mathrm{CH}_{2} \mathrm{Cl}_{2}$-EtOAc (90:10; 80:20 and 70:30, $v / v$, respectively) was submitted to silica gel CC eluted with hexane-EtOAc (100:0 to 50:50, $v / v)$ and EtOAc-MeOH (100:0 to 20:80, $v / v)$ affording 34 subfractions $(25 \mathrm{~mL}$ each), which were pooled into 10 subgroups (G14.1 to G14.10). Subgroup G14.7 (31.6 mg) from CC eluted with hexane-EtOAc (80:20, $v / v)$ was submitted to a preparative TLC eluted with hexaneEtOAc (80:20, v/v, two elutions) and yielded 4 (11.4 mg).

Group G15 (299.0 mg), from CC eluted with $\mathrm{CH}_{2} \mathrm{Cl}_{2}$-EtOAc (50:50 and 30:70, v/v, respectively, and EtOAc 100\%) was submitted to silica gel CC eluted with hexane-EtOAc (100:0 to 50:50, v/v), followed by EtOAc-MeOH (100:0 to 20:80, v/v) and yielded 39 subfractions $(25 \mathrm{~mL}$ each) that were subsequently pooled into 8 groups (G15.1 to G15.8). Subgroup G15.4 (108.9 mg) from CC eluted with hexane-EtOAc (50:50 and 40:60, $v / v$, respectively) was obtained as crystalline white solid that showed high purity by GC-MS analysis and yielded $\mathbf{5}$ (108.9 $\mathrm{mg})$.

Group G19 (70.0 mg) from CC eluted with EtOAc-MeOH (70:30 and 50:50, $v / v$, respectively) was submitted to a preparative TLC eluted with hexane-EtOAc (70:30, $v / v$, four elutions), and yielded 6 (5.3 mg).

Abieta-7,13-dien-3-one (1): Yellow oil $\left(\mathrm{CHCl}_{3}\right) ;[\alpha]_{\mathrm{D}}{ }^{25}+30.81^{\circ}(\mathrm{c}$ 1.0, $\left.\mathrm{CHCl}_{3}\right) ;{ }^{1} \mathrm{H}$ and ${ }^{13} \mathrm{C}$ NMR data see Table 2; EI-MS $m / z, 286[\mathrm{M}]^{+\bullet}$.

Spathulenol (2): Colorless oil $\left(\mathrm{CHCl}_{3}\right) ;[\alpha]_{\mathrm{D}}^{25}+4.20^{\circ}$ (c 1.2, $\left.\mathrm{CHCl}_{3}\right)$; The ${ }^{1} \mathrm{H}$ and ${ }^{13} \mathrm{C}$ NMR data were in agreement with those from the literature, ${ }^{24} \mathrm{EI}-\mathrm{MS} \mathrm{m} / \mathrm{z}, 220[\mathrm{M}]^{+\bullet}$.

ent-7 $\beta$-Acetoxy-16 $\beta$-hydroxy-kaurane (3): Amorphous white solid $\left(\mathrm{CHCl}_{3}\right) ;[\alpha]_{\mathrm{D}}{ }^{25}-1.00^{\circ}\left(c 0.4, \mathrm{CHCl}_{3}\right) ;{ }^{1} \mathrm{H}$ and ${ }^{13} \mathrm{C}$ NMR data see Table 1; HR-ESIMS $371.2558[\mathrm{M}+\mathrm{Na}]^{+}\left(\mathrm{C}_{22} \mathrm{H}_{36} \mathrm{O}_{3}+\mathrm{Na}\right.$; calc. 371.2562); EI-MS m/z $270\left[\mathrm{M}-\mathrm{H}_{2} \mathrm{O}-\mathrm{C}_{2} \mathrm{H}_{3} \mathrm{O}_{2}\right]^{+\bullet}$.

4-epi-Cupressic acid [13-Hydroxy-ent-labda-8,14-dien-18-oic acid] (4): Crystalline white solid $\left(\mathrm{CHCl}_{3}\right) ;[\alpha]_{\mathrm{D}}{ }^{25}-57.12^{\circ}$ (c 0.06, $\left.\mathrm{CHCl}_{3}\right) ;{ }^{1} \mathrm{H}$ and ${ }^{13} \mathrm{C}$ NMR data see Table 2; HR-ESIMS 319.2262 $[\mathrm{M}-\mathrm{H}]^{-}\left(\mathrm{C}_{20} \mathrm{H}_{32} \mathrm{O}_{3}-\mathrm{H}\right.$; calc. 319.2273).

Powerol [(-)Kaurane-7ß,16a-diol] (5): Crystalline white solid 
$\left(\mathrm{CH}_{2} \mathrm{Cl}_{2}\right) ;[\alpha]_{\mathrm{D}}{ }^{25}-2.70^{\circ}\left(c 0.5, \mathrm{CHCl}_{3}\right) ;{ }^{1} \mathrm{H}$ and ${ }^{13} \mathrm{C}$ NMR data see Table 1; HR-ESIMS 305.2129 [M-H] $]^{-}\left(\mathrm{C}_{20} \mathrm{H}_{34} \mathrm{O}_{2}-\mathrm{H}\right.$; calc. 305.2480); HRESIMS 329.2453 [M+Na] ${ }^{+}\left(\mathrm{C}_{20} \mathrm{H}_{34} \mathrm{O}_{2}+\mathrm{Na}\right.$; calc. 329.2456); EI-MS $\mathrm{m} / \mathrm{z} 306[\mathrm{M}]^{+\bullet}$.

Labdorffianic acid $B$ [8,20-Epoxy-13-hydroxy-ent-labda14-en-18-oic acid] (6): Colorless oil $\left(\mathrm{CHCl}_{3}\right) ;[\alpha]_{\mathrm{D}}{ }^{25}-36.1^{\circ}(c 0.2$, $\left.\mathrm{CHCl}_{3}\right) ;{ }^{1} \mathrm{H}$ and ${ }^{13} \mathrm{CNMR}$ data see Table 2; LR-ESIMS [M-H] ${ }^{-} \mathrm{m} / z 335$.

\section{Cytotoxicity assay}

Tumor cell lines: B16-F10 (mouse melanoma), HepG2 (human hepatocellular carcinoma), K562 (human chronic myelocytic leukemia) and HL-60 (human promyelocytic leukemia) were kindly provided by the A.C. Camargo Hospital, São Paulo, Brazil. Cells were maintained in Roswell Park Memorial Institute-1640 (RPMI-1640) medium with $10 \%$ fetal bovine serum, $2 \mathrm{mmol} \mathrm{L}^{-1}$ glutamine, and $50 \mu \mathrm{g} \mathrm{mL} \mathrm{m}^{-1}$ gentamycin. Adherent cells were collected by treatment with a $0.25 \%$ trypsin-EDTA solution. All cell lines were cultured in cell culture flasks at $37^{\circ} \mathrm{C}$ in $5 \% \mathrm{CO}_{2}$ and sub-cultured every 3-4 days to maintain exponential growth. All experiments were performed with cells in the exponential growth phase. All cell lines were evaluated for mycoplasma using on a Sigma-Aldrich Mycoplasma stain kit, and all cells were free from contamination. Heparinized blood (from 20-35-year-old, healthy, non-smokers who had not taken any drugs for at least 15 days prior to sampling) was collected, and peripheral blood mononuclear cells (PBMCs) were isolated using a standard protocol which used a Ficoll density gradient in a GE Ficoll-Paque Plus. PBMCs were washed and re-suspended at a concentration of $0.3 \times 10^{6}$ cells $\mathrm{mL}^{-1}$ in RPMI-1640 medium with $20 \%$ fetal bovine serum, $2 \mathrm{mmol}$ glutamine, and $50 \mu \mathrm{g} \mathrm{mL}^{-1}$ gentamycin at $37^{\circ} \mathrm{C}$ with $5 \% \mathrm{CO}_{2}$. Concanavalin $\mathrm{A}(\mathrm{ConA})$ was used as a mitogen to trigger cell division in T-lymphocytes. ConA $\left(10 \mu \mathrm{g} \mathrm{mL}^{-1}\right)$ was added at the beginning of culture, and cells were treated with the compounds after $24 \mathrm{~h}$. Over $90 \%$ of the cells were viable at the beginning of the culture, according to the Trypan blue exclusion assay. Cell growth was quantified using the Alamar blue assay. Cells were seeded in 96 -well plates for all experiments $\left(0.7 \times 10^{5}\right.$ cells $\mathrm{mL}^{-1}$ for adherent cells or $0.3 \times 10^{6}$ cells $\mathrm{mL}^{-1}$ for suspended cells in $100 \mu \mathrm{L}$ of medium). ${ }^{25}$ After $24 \mathrm{~h}$ of incubation, the compounds (dissolved in DMSO at a concentration of $0.19-25 \mu \mathrm{g} \mathrm{mL}^{-1}$ ) were added and incubated for $72 \mathrm{~h}$. Doxorubicin was used as the positive control (0.08-5 $\left.\mu \mathrm{g} \mathrm{mL}^{-1}\right)$, while DMSO $(0.5 \%)$ was used as negative control. Four hours (for tumor cell lines) and $24 \mathrm{~h}$ (for PBMCs) before the endo of incubation period, $20 \mu \mathrm{L}$ of Alamar blue reagent were added to each well. Subsequently, absorbance was measured on a Spectra Max 190 multiplate reader at $570 \mathrm{~nm}$ and $600 \mathrm{~nm}$. Half-inhibitory concentration $\left(\mathrm{IC}_{50}\right)$ was obtained by nonlinear regression with $95 \%$ confidence intervals (CI 95\%).

\section{RESULTS AND DISCUSSION}

The phytochemical investigation of the hexane extract from the leaves of $X$. laevigata (Annonaceae) yielded six compounds (Figure 1), including one uncommon ent-kaurene diterpenoid ent-7 $\beta$-acetoxy-16 $\beta$-hydroxy-kaurane (3), in addition to other five isolated compounds, abieta-7,13-dien-3-one (1), ${ }^{26}$ spathulenol (2), ${ }^{24}$ 13-hydroxy-ent-labda-8,14-dien-18-oic acid (4-epi-cupressic acid) (4), ${ }^{27}$ (-)-kaurane-7 $\beta, 16 \alpha$-diol (powerol) $(5),{ }^{28}$ and 8,20-epoxy13-hydroxy-ent-labda-14-en-18-oic acid (labdorffianic acid B) (6). ${ }^{29}$

Compound 3 was obtained as a white amorphous powder with the molecular formula $\mathrm{C}_{22} \mathrm{H}_{36} \mathrm{O}_{3}$ as determined by HR-ESIMS $\left(\mathrm{m} / \mathrm{z} 371.2558[\mathrm{M}+\mathrm{Na}]^{+}\right.$, calc. 371.2562) and NMR data. HRESIMS also showed a fragment at $m / z, 271.2440\left[\mathrm{M}-\mathrm{H}_{2} \mathrm{O}-\mathrm{C}_{2} \mathrm{H}_{3} \mathrm{O}_{2}\right]^{+}$<smiles>CC(C)C1=CC2=CCC3C(C)(C)C(=O)CC[C@]3(C)C2CC1</smiles><smiles>C=C1CCC2C(C3C1CC[C@@H]3O)C2(C)C</smiles>
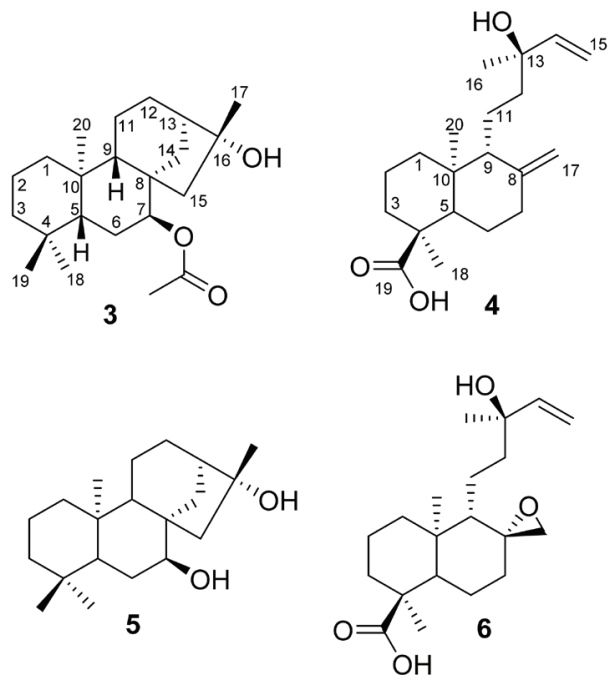

Figure 1. Chemical structures of the isolated compounds 1-6

(Figure 2), which is in agreement with the fragment at $\mathrm{m} / \mathrm{z}, 270$ $\left[\mathrm{M}-\mathrm{H}_{2} \mathrm{O}-\mathrm{C}_{2} \mathrm{H}_{3} \mathrm{O}_{2}\right]^{+\bullet}$ observed using the GC-MS analysis. The ${ }^{1} \mathrm{H}$ NMR spectrum displayed the characteristic signals of four methyl groups, which are characteristic of diterpenes from the kaurane series, and typical for C-17, C-18 $\mathrm{ax}, \mathrm{C}-19_{\mathrm{eq}}$ and C-20 ${ }_{\mathrm{ax}}{ }^{25}$ The signals at $\delta_{H} 2.05(s, 3 \mathrm{H})$ and $\delta_{H} 4.62(d d, J=2.8$ and $2.9 \mathrm{~Hz}, 1 \mathrm{H})$ revealed the presence of an acetoxy group and an oxygenated carbon in the structure, respectively. The ${ }^{13} \mathrm{C}\left\{{ }^{1} \mathrm{H}\right\}$ and DEPT135 NMR spectra, as well as one-bond and long-range ${ }^{1} \mathrm{H}_{-1}{ }^{13} \mathrm{C}$ correlations from HSQC and HMBC NMR experiments indicated a total of 22 carbon atoms, which comprised of five methyls, eight methylenes, four methines (one oxygenated at $\delta_{C} 76.2$ ), four quaternary carbons (one oxygenated at $\delta_{C}$ 72.0), and one acetoxy group (Table 1). The hydrogen signal at $\delta_{H} 4.62(\mathrm{H}-7)$ showed direct ${ }^{1} \mathrm{H}-{ }^{13} \mathrm{C}$ correlation with the carbon at $\delta_{C} 76.2$ and long-range ${ }^{1} \mathrm{H}^{-13} \mathrm{C}$ correlations with the carbons at $\delta_{C} 46.8$ (C-9), $\delta_{C} 48.1$ (C-5) and $\delta_{C} 170.5$, which supports the substitution pattern proposed with the acetoxy group placed at C-7 (Figure 3).

The relative configuration of this compound was determined via $1 \mathrm{D}$ NOESY NMR experiments. The selective irradiation of the NMR frequency of the methyl group at $\delta_{H} 2.05(s)$ caused a NOE enhancement in the signals at $\delta_{H} 4.62\left(d d, J=2.9\right.$ and $\left.2.8 \mathrm{~Hz}, \mathrm{H}-7_{\mathrm{eq}}\right)$, $\delta_{H} 1.66\left(m, \mathrm{H}-6_{\mathrm{eq}}\right), \delta_{H} 1.57\left(m, \mathrm{H}-9_{\mathrm{ax}}\right), \delta_{H} 1.31(d d, J=9.1$ and $2.8 \mathrm{~Hz}$, $\left.\mathrm{H}-5_{\mathrm{ax}}\right), \delta_{H} 1.19\left(d, J=13.6 \mathrm{~Hz}, \mathrm{H}-15_{\mathrm{ax}}\right)$, and $\delta_{H} 0.78\left(s, \mathrm{H}-19_{\mathrm{eq}}\right)$. Similarly, the selective irradiation of $\mathrm{H}-7$ caused NOE intensification of the signals at $\delta_{H} 1.63\left(m, \mathrm{H}-6_{\mathrm{ax}}\right), \delta_{H} 1.66\left(\mathrm{H}-6_{\mathrm{eq}}\right), \delta_{H} 0.98\left(\mathrm{H}-14_{\mathrm{eq}}\right)$, and $\delta_{H} 1.19\left(\mathrm{H}-15_{\mathrm{pax}}\right)$, which confirmed the $\beta$-orientation of the acetoxy group at C-7 (i.e. acetoxy group is in axial position). On the other hand, the selective irradiation of NMR frequency of H-17 (methyl group) caused a NOE enhancement in the signals at $\delta_{H} 1.19$ $\left(\mathrm{H}-15_{\mathrm{ax}}\right)$ and $\delta_{H} 1.53\left(\mathrm{~m}, \mathrm{H}-13_{\mathrm{eq}}\right)$, which confirms the presence of a hydroxyl group in $\beta$-orientation at the $\mathrm{C}-16$ position (i.e. the hydroxyl group is in an axial position). Furthermore, the selective irradiation of H-18 at $\delta_{H} 0.80$ caused a NOE enhancement of the signals at $\delta_{H} 0.78\left(s, \mathrm{H}-19_{\mathrm{eq}}\right), \delta_{H} 0.96\left(s, \mathrm{H}-20_{\mathrm{ax}}\right), \delta_{H} 1.41\left(m, \mathrm{H}-3_{\mathrm{eq}}\right)$, and $\delta_{H} 1.60\left(\mathrm{H}-6_{\mathrm{ax}}\right)$. The selective irradiation of a singlet at $\delta_{H} 0.78(\mathrm{H}-19)$ showed NOE intensifications at $\delta_{H} 1.17\left(m, \mathrm{H}-3_{\mathrm{ax}}\right), \delta_{H} 1.41\left(m, \mathrm{H}-3_{\mathrm{eq}}\right)$, 


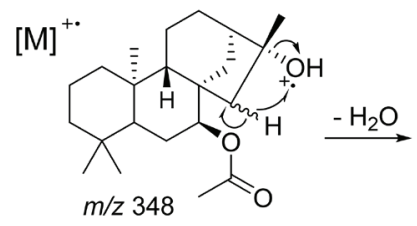

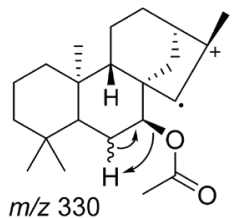
$\mathrm{m} / \mathrm{z} 330$<smiles>CCCCO[O+]</smiles>

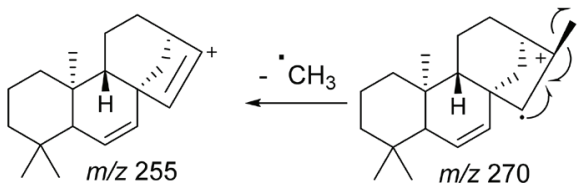

Figure 2. Proposed fragmentation pathway for compound $\mathbf{3}$
$\delta_{H} 1.31\left(d d, \mathrm{H}-5_{\mathrm{ax}}\right), \delta_{H} 1.66\left(\mathrm{H}-6_{\mathrm{eq}}\right), \delta_{H} 2.05\left(s, \mathrm{CH}_{3} \mathrm{COO}\right)$, and some intensification of the signal at $\delta_{H} 0.96\left(\mathrm{H}-20_{\mathrm{ax}}\right)$. These observations confirm the axial and equatorial orientations of the methyl groups at C-18 and C-19, respectively. Likewise, the selective irradiation of $\mathrm{H}-20$ at $\delta_{H} 0.96$ caused NOE intensifications at the signals at $\delta_{H} 0.80$ $\left(s, \mathrm{H}-18_{\mathrm{ax}}\right), \delta_{H} 1.70\left(m, \mathrm{H}-14_{\mathrm{ax}}\right), \delta_{H} 1.59\left(m, \mathrm{H}-2_{\mathrm{ax}}\right)$, and $\delta_{H} 1.60(m$, H- $\left.6_{\mathrm{ax}}\right)$, this fact proves the $\beta$-orientation of the methyl group C-20 (Figure 3). The exhaustive analysis of 1D and 2D NMR data enabled the structure to be fully established, and ${ }^{1} \mathrm{H}$ and ${ }^{13} \mathrm{C}$ NMR chemical shifts unequivocally assigned (Table 1). Therefore, compound $\mathbf{3}$ was identified as the known ent-kaurane diterpene called ent-7 $\beta$-acetoxy$16 \beta$-hydroxy-kaurane (also known powerol $7 \beta$-acetate), which was a product of acetylation of (-)-kaurane-7 $\beta, 16 \alpha$-diol (powerol) (5) (Table 1). Therefore, this is the first report of compound $\mathbf{3}$ as a natural product, as well as its second report in the literature. According to
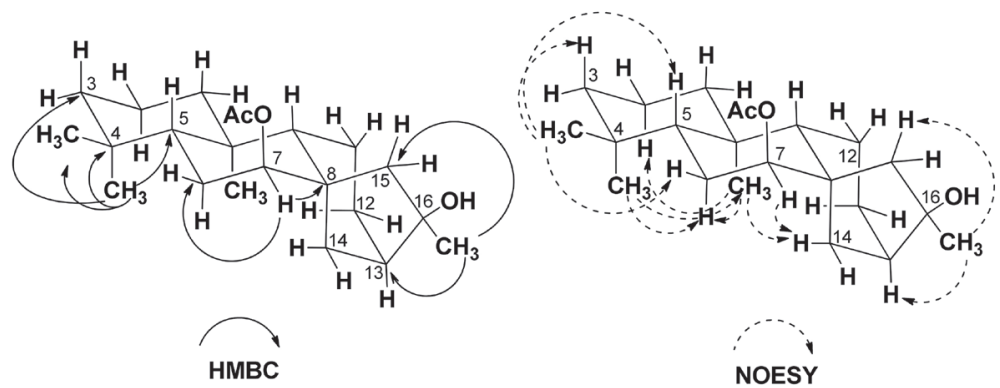

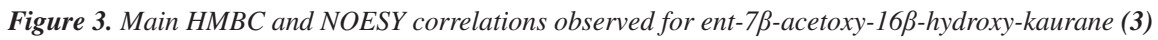

Table 1. NMR data for ent-7 $\beta$-acetoxy-16ß-hydroxy-kaurane (3) and powerol (5) $\left(\mathrm{CDCl}_{3}, 600 \mathrm{MHz}\right)$

\begin{tabular}{|c|c|c|c|c|}
\hline \multirow{2}{*}{ Position } & \multicolumn{2}{|c|}{ ent-7 $\beta$-acetoxy-16 $\beta$-hydroxy-kaurane (3) } & \multicolumn{2}{|r|}{ Powerol (5) } \\
\hline & $\delta_{C}$ & $\delta_{H}$ mult. $(J$ in $\mathrm{Hz})$ & $\delta_{C}$ & $\delta_{\mathrm{H}}$ mult. $(J$ in $\mathrm{Hz})$ \\
\hline 1 & 39.1 & $\begin{array}{l}\text { ax } 0.88 \mathrm{~m} \\
\text { eq } 1.55 \mathrm{~m}\end{array}$ & 39.2 & $\begin{array}{l}\text { ax } 0.88 \mathrm{~m} \\
\text { eq } 1.53 \mathrm{~m}\end{array}$ \\
\hline 2 & 18.1 & $\begin{array}{l}\text { ax } 1.59 \mathrm{~m} \\
\text { eq } 1.40 \mathrm{~m}\end{array}$ & 18.2 & $\begin{array}{l}\text { ax } 1.59 \mathrm{~m} \\
\text { eq } 1.40 \mathrm{~m}\end{array}$ \\
\hline 3 & 42.0 & $\begin{array}{l}\text { ax } 1.17 \mathrm{~m} \\
\text { eq } 1.41 \mathrm{~m}\end{array}$ & 42.1 & $\begin{array}{l}\text { ax } 1.20 \mathrm{~m} \\
\text { eq } 1.41 \mathrm{~m}\end{array}$ \\
\hline 4 & 32.5 & & 32.6 & \\
\hline 5 & 48.1 & ax $1.31 d d(9.1$ and 2.8$)$ & 47.3 & $1.35 d d(12.3$ and 2.8$)$ \\
\hline 6 & 24.0 & $\begin{array}{l}\text { ax } 1.60 \mathrm{~m} \\
\text { eq } 1.66 \mathrm{~m}\end{array}$ & 26.9 & $\begin{array}{l}\text { ax } 1.61 \mathrm{~m} \\
\text { eq } 1.63 \mathrm{~m}\end{array}$ \\
\hline 7 & 76.2 & eq $4.62 d d(2.9$ and 2.8$)$ & 73.9 & eq $3.39 d d(2.9$ and 2.8$)$ \\
\hline 8 & 37.1 & & 32.6 & \\
\hline 9 & 46.8 & ax $1.57 \mathrm{~m}$ & 46.1 & ax $1.53 \mathrm{~m}$ \\
\hline 10 & 37.6 & & 37.8 & \\
\hline 11 & 22.5 & $\begin{array}{l}\text { ax } 1.18 \mathrm{~m} \\
\text { eq } 1.99 \mathrm{~m}\end{array}$ & 23.6 & $\begin{array}{l}\text { ax } 1.50 \mathrm{~m} \\
\text { eq } 1.66 \mathrm{~m}\end{array}$ \\
\hline 12 & 23.4 & $\begin{array}{l}\text { ax } 1.24 m \\
\text { eq } 1.52 m\end{array}$ & 22.5 & $\begin{array}{c}\text { ax } 1.98 d d d d(14.5,11.7,3.0 \text { and } 3.0) \\
\text { eq } 1.17 \mathrm{~m}\end{array}$ \\
\hline 13 & 37.8 & eq $1.53 \mathrm{~m}$ & 37.8 & $1.54 \mathrm{~m}$ \\
\hline 14 & 26.5 & $\begin{array}{l}\text { ax } 1.70 \mathrm{~m} \\
\text { eq } 0.98 \mathrm{~m}\end{array}$ & 26.8 & $\begin{array}{l}\text { ax } 1.63 \mathrm{~m} \\
\text { eq } 0.90 \mathrm{~m}\end{array}$ \\
\hline 15 & 50.4 & $\begin{array}{l}\text { ax } 1.19 d(13.6) \\
\text { eq } 1.56 d(13.6)\end{array}$ & 51.4 & $\begin{array}{l}\text { ax } 1.27 m \\
\text { eq } 1.72 m\end{array}$ \\
\hline 16 & 72.0 & & 72.2 & \\
\hline 17 & 30.6 & $1.29 \mathrm{~s}$ & 30.6 & $1.31 \mathrm{~s}$ \\
\hline 18 & 21.5 & $0.80 s$ & 21.7 & $0.82 s$ \\
\hline 19 & 33.0 & $0.78 s$ & 33.2 & $0.86 s$ \\
\hline 20 & 13.4 & $0.96 s$ & 13.5 & $0.95 s$ \\
\hline $\mathrm{CH}_{3} \mathrm{COO}-7$ & 170.5 & & & \\
\hline $\mathrm{CH}_{3} \mathrm{COO}-7$ & 21.2 & $2.05 s$ & & \\
\hline
\end{tabular}


previously published literature data, ${ }^{28}$ only some ${ }^{1} \mathrm{H}$ NMR resonances were described for this compound, which enabled us to extensively revise $1 \mathrm{D}$ and 2D NMR data and unequivocally assign the chemical shifts of hydrogen and carbon atoms (Table 1), and its relative configuration.

The isolated compounds: abieta-7,13-dien-3-one (1) ${ }^{26}$ spathulenol (2), ${ }^{24}$ 13-hydroxy-ent-labda-8,14-dien-18-oic acid (4), ${ }^{27}$ (-)-kaurane$7 \beta, 16 \alpha$-diol (5), ${ }^{28}$ and 8,20-epoxy-13-hydroxy-ent-labda-14-en18-oic acid $(\mathbf{6})^{29}$ were identified by comparison of their NMR and MS data with those previously reported in the literature. Nevertheless, compounds 1, 4, and $\mathbf{6}$ have been described a long time ago and their published NMR data was incomplete $\left({ }^{1} \mathrm{H}\right.$ and $\left.{ }^{13} \mathrm{C} \mathrm{NMR}\right)$. As well as showing some ambiguities in the scalar coupling constants, most of them not been previously assigned..$^{26,27-29}$ Therefore, the complete and unequivocal NMR data for these diterpenes were reviewed according to the 1D and 2D NMR experiments (Tables 1 and 2).

The absolute configurations of the diterpenoids from the ent and normal series can be established based on their specific rotations $\left([\alpha]_{\mathrm{D}}\right)$, since they can be correlated to similar diterpenes with welldefined absolute configurations. ${ }^{30}$ Therefore, those that divert to the right $(+)$ belong to the normal series, while those that divert the polarized light to the left $(-)$ belong to the ent series. ${ }^{30}$ Thus, it was established that the diterpenes $\mathbf{3}\left([\alpha]_{\mathrm{D}}{ }^{25}-1.00^{\circ}\right)$ and $\mathbf{5}\left([\alpha]_{\mathrm{D}}{ }^{25}-2.70^{\circ}\right)$ belong to the ent series. ${ }^{30}$

Diterpenes of ent-kaurane type are common in Annonnaceae, especially in the species of Annona and Xylopia. ${ }^{31-34}$ The presence of other diterpene types in X. laevigata indicates that Xylopia species have a strong ability to produce different diterpenes (compounds $\mathbf{1 , 4}$ and 6) and suggest the need for more investigation in order to confirm the presence of other compounds of these types in this species, as well as other Xylopia spp., such as $\mathbf{6}$, that has been only previously reported as occurring in Xylopia langsdorffiana. ${ }^{30}$ On the other hand, diterpenes 1, 3, 4, and 5 have been reported for the first time in Annonaceae. The occurrence of diterpenes possessing the acetoxy function was described previously in Annonaceae. ${ }^{31-34}$ Therefore, this study contributes to the chemotaxonomy of the genus Xylopia, as well as to the Annonaceae family.

The cytotoxic activity of the isolated compounds 1, 2, 4 and 5 was evaluated against tumor (B16-F10, HepG2, HL-60, and K562) and non-tumor (PBMC) cell lines (Table 3) with increasing concentrations under $72 \mathrm{~h}$ of incubation and analyzed using the Alamar blue assay. Compared to the positive control (doxorubicin), compound $\mathbf{2}$ exhibited a moderate cytotoxic effect by showing $\mathrm{IC}_{50}$ from 17.20 to $50.78 \mu \mathrm{mol} \mathrm{\textrm {L } ^ { - 1 }}$ for the tumor cell lines tested (Table 3). For K562, compound 2 showed a significant cytotoxic effect with an $\mathrm{IC}_{50}$ value of $17.20 \mu \mathrm{mol} \mathrm{L}{ }^{-1}$. However, the cytotoxic activity against the normal cell PBMC $\left(\mathrm{IC}_{50}=70.75 \mu \mathrm{mol} \mathrm{L}{ }^{-1}\right)$ was considered moderate, since it showed slow selectivity against K562. Furthermore, compound $\mathbf{5}$ also exhibited moderate cytotoxic effect against B16-F10, HL-60, and $\mathrm{K} 562$ tumor cell lines with an $\mathrm{IC}_{50}$ of $80.36,47.11$, and $64.60 \mu \mathrm{mol} \mathrm{L}{ }^{-1}$, respectively, although, it was inactive against HepG2 cell line $\left(\mathrm{IC}_{50}\right.$ greater than $\left.81.57 \mu \mathrm{mol} \mathrm{L}-1\right)$

Table 2. NMR data for abieta-7,13-dien-3-one (1), 4-epi-cupressic acid (4) and labdorffianic acid B (6) $\left(\mathrm{CDCl}_{3}, 600 \mathrm{MHz}\right)$

\begin{tabular}{|c|c|c|c|c|c|c|}
\hline \multirow{2}{*}{ Position } & \multicolumn{2}{|r|}{ abieta-7,13-dien-3-one (1) } & \multicolumn{2}{|r|}{ 4-epi-cupressic acid (4) } & \multicolumn{2}{|r|}{ labdorffianic acid B (6) } \\
\hline & $\delta_{C}$ & $\delta_{H}$ mult. $(J$ in $\mathrm{Hz})$ & $\delta_{C}$ & $\delta_{H}$ mult. $(J$ in $\mathrm{Hz})$ & $\delta_{C}$ & $\delta_{H}$ mult. $(\mathrm{J}$ in $\mathrm{Hz})$ \\
\hline 1 & 38.1 & $\begin{array}{l}\text { ax } 1.51 d d d(14.5,13.5 \text { and } 3.9) \\
\text { eq } 2.17 d d d(13.5,5.3 \text { and } 3.6)\end{array}$ & 38.0 & $\begin{array}{l}\text { ax } 1.15 \mathrm{~m} \\
\text { eq } 1.81 \mathrm{~m}\end{array}$ & 38.0 & $\begin{array}{l}\text { ax } 1.15 \mathrm{~m} \\
\text { eq } 1.78 \mathrm{~m}\end{array}$ \\
\hline 2 & 34.8 & $\begin{array}{l}\text { ax } 2.28 d d d(14.4,3.9 \text { and } 3.6) \\
\text { eq } 2.76 d d d(14.5,14.4 \text { and 5.3) }\end{array}$ & 18.4 & $\begin{array}{l}\text { ax } 1.60 \mathrm{~m} \\
\text { eq } 1.78 \mathrm{~m}\end{array}$ & 17.6 & $\begin{array}{l}\text { ax } 1.58 \mathrm{~m} \\
\text { eq } 1.61 \mathrm{~m}\end{array}$ \\
\hline 3 & 216.9 & & 37.1 & $\begin{array}{l}\text { ax } 1.63 \mathrm{~m} \\
\text { eq } 1.79 \mathrm{~m}\end{array}$ & 37.0 & $\begin{array}{l}\text { ax } 1.63 \mathrm{~m} \\
\text { eq } 1.77 \mathrm{~m}\end{array}$ \\
\hline 4 & 47.6 & & 47.5 & & 47.2 & \\
\hline 5 & 51.4 & $1.66 d d(11.8$ and 5.0) & 49.6 & $1.95 d d(12.5$ and 2.8$)$ & 49.2 & $1.88 d d(12.4$ and 4.6$)$ \\
\hline 6 & 24.2 & $\begin{array}{l}\text { ax } 2.09 \mathrm{~m} \\
\text { eq } 2.16 \mathrm{~m}\end{array}$ & 26.8 & $\begin{array}{l}\text { eq } 1.35 d d d d(12.8,5.4,2.8 \text { and } 2.3) \\
\text { ax } 1.46 d d d d(13.1,12.8,12.5 \text { and } 4.3)\end{array}$ & 24.3 & $\begin{array}{l}\text { ax } 1.45 \mathrm{~m} \\
\text { eq } 1.60 \mathrm{~m}\end{array}$ \\
\hline 7 & 120.7 & $5.47 \mathrm{~m}$ & 37.8 & $\begin{array}{l}\text { ax } 2.04 d d d(13.1,12.7 \text { and 5.4) } \\
\text { eq } 2.34 d d d(12.7,4.3 \text { and } 2.3)\end{array}$ & 36.2 & $\begin{array}{c}\text { eq } 1.33 d d d(12.6,4.4 \text { and } 2.5) \\
\text { ax } 1.94 d d d d(12.8,12.6,4.7 \text { and } 1.8)\end{array}$ \\
\hline 8 & 135.3 & & 148.0 & & 59.2 & \\
\hline 9 & 50.0 & $1.89 \mathrm{~m}$ & 57.2 & $1.65 \mathrm{~m}$ & 54.2 & $1.52 \mathrm{~m}$ \\
\hline 10 & 34.8 & & 39.1 & & 39.7 & \\
\hline 11 & 22.7 & $\begin{array}{l}\text { ax } 1.29 m \\
\text { eq } 1.84 m\end{array}$ & 17.5 & $\begin{array}{l}1.32 \mathrm{~m} \\
1.55 \mathrm{~m}\end{array}$ & 15.9 & $\begin{array}{l}0.78 \mathrm{~m} \\
1.21 \mathrm{~m}\end{array}$ \\
\hline 12 & 27.4 & $\begin{array}{l}\text { ax } 2.10 \mathrm{~m} \\
\text { eq } 2.11 \mathrm{~m}\end{array}$ & 41.2 & $\begin{array}{l}1.34 \mathrm{~m} \\
1.71 \mathrm{~m}\end{array}$ & 43.6 & $\begin{array}{l}1.51 \mathrm{~m} \\
1.65 \mathrm{~m}\end{array}$ \\
\hline 13 & 145.8 & & 73.7 & & 73.5 & \\
\hline 14 & 122.1 & $5.81 \mathrm{~m}$ & 145.0 & $5.90 d d(17.3$ and 10.8$)$ & 145.4 & $5.88 d d(17.3$ and 10.7$)$ \\
\hline 15 & 34.9 & $2.24 \mathrm{~m}$ & 111.7 & $\begin{array}{l}5.07 d d(10.8 \text { and } 1.1) \\
5.21 d d(17.3 \text { and } 1.1)\end{array}$ & 111.4 & $\begin{array}{l}5.02 d d(10.7 \text { and } 1.3) \\
5.19 d d(17.3 \text { and } 1.3)\end{array}$ \\
\hline 16 & 21.4 & $1.01 d(6.7)$ & 28.1 & $1.27 \mathrm{~s}$ & 27.9 & $1.22 \mathrm{~s}$ \\
\hline 17 & 20.8 & $1.02 d(6.7)$ & 107.1 & $\begin{array}{l}4.50 d(1.2) \\
4.82 d(1.2)\end{array}$ & 50.7 & $\begin{array}{c}2.48 d(4.3) \\
2.77 d d(4.3 \text { and } 1.8)\end{array}$ \\
\hline 18 & 22.2 & $1.14 s$ & 16.4 & $1.14 s$ & 16.3 & $1.17 \mathrm{~s}$ \\
\hline 19 & 25.0 & $1.07 \mathrm{~s}$ & 184.3 & & 183.9 & \\
\hline 20 & 13.4 & $1.03 \mathrm{~s}$ & 14.7 & $0.70 s$ & 14.9 & $0.82 s$ \\
\hline
\end{tabular}

${ }^{a} \mathrm{NMR}$ experiment results were acquired at $303 \mathrm{~K}$ with TMS as internal reference at $0.00 \mathrm{ppm}$ in $\mathrm{CDCl}_{3} \cdot{ }^{\mathrm{b}}$ Multiplicities determined by DEPT 135 , HSQC and HMBC experiments. 
Table 3. In vitro cytotoxic activity

\begin{tabular}{|c|c|c|c|c|c|}
\hline \multirow{2}{*}{ Compounds } & \multicolumn{5}{|c|}{$\mathrm{IC}_{50} \mu \mathrm{mol} \mathrm{L}-1$} \\
\hline & B16-F10 & HepG2 & HL-60 & K562 & PBMC \\
\hline 1 & $>87.27$ & $>87.27$ & $>87.27$ & $>87.27$ & $>87.27$ \\
\hline 2 & $\begin{array}{c}52.96 \\
44.36-63.46\end{array}$ & $\begin{array}{c}50.78 \\
43.55-59.41\end{array}$ & $\begin{array}{c}51.65 \\
38.46-69.59\end{array}$ & $\begin{array}{c}17.20 \\
6.73-44.09\end{array}$ & $\begin{array}{c}70.75 \\
59.64-84.23\end{array}$ \\
\hline 4 & $>78.01$ & $>78.01$ & $>78.01$ & $>78.01$ & $>78.01$ \\
\hline 5 & $\begin{array}{c}80.36 \\
73.37-88.30\end{array}$ & $>81.57$ & $\begin{array}{c}47.11 \\
26.24-84.80\end{array}$ & $\begin{array}{c}64.60 \\
50.65-82.68\end{array}$ & $>81.57$ \\
\hline Doxorubicin & $\begin{array}{c}0.15 \\
0.09-0.26\end{array}$ & $\begin{array}{c}0.15 \\
0.11-0.18\end{array}$ & $\begin{array}{c}0.17 \\
0.11-0.22\end{array}$ & $\begin{array}{c}0.28 \\
0.15-0.57\end{array}$ & $\begin{array}{c}4.54 \\
3.31-6.24\end{array}$ \\
\hline
\end{tabular}

Data are presented as $\mathrm{IC}_{50}$ values, in $\mu \mathrm{mol} \mathrm{L} \mathrm{L}^{-1}$, obtained by nonlinear regression from three independent experiments performed in duplicate, measured using Alamar blue assay after $72 \mathrm{~h}$ incubation. Tumor cells: B16-F10 (mouse melanoma), HepG2 (human hepatocellular carcinoma), HL-60 (human promyelocytic leukemia) and K562 (human chronic myelocytic leukemia). Non-tumor cell: PBMC (human peripheral blood mononuclear cells activated with concanavalin A human lymphoblast). Doxorubicin was used as the positive control.

(Table 3). On the other hand, this compound was also considered not to be cytotoxic for normal cell lines of $\mathrm{IC}_{50}\left(\mathrm{IC}_{50}>81.57 \mu \mathrm{mol} \mathrm{L}-1\right)$. Doxorubicin presented $\mathrm{IC}_{50}$ values which ranged from $0.15 \mu \mathrm{mol} \mathrm{\textrm {L } ^ { - 1 }}$ to $0.28 \mu \mathrm{mol} \mathrm{L}-1$ for the tumor cell lines evaluated (Table 3 ). In addition, doxorubicin also displayed cytotoxic activity against PBMC with $\mathrm{IC}_{50}$ value of $4.54 \mu \mathrm{mol} \mathrm{L}{ }^{-1}$. However, it is important to mention that doxorubicin is the drug used in the treatment of cancer, though also responsible for serious collateral effects.

\section{CONCLUSION}

The phytochemical investigation of the hexane extract of the leaves of $X$. laevigata yielded six terpenoids, including an uncommon diterpene known as ent-7 $\beta$-acetoxy-16 $\beta$-hydroxy-kaurane (3), herein reported for the first time as a natural product. Compounds 1, 3, 4, and $\mathbf{5}$ are described here for the first time within the family Annonaceae. This work reinforces the fact that Xylopia is a rich, natural source for different types of diterpernes. Besides this, spathulenol (2) showed moderated cytotoxicity against all cell lines tested, while powerol (5) displayed weak activity.

\section{SUPPLEMENTARY MATERIAL}

Supplementary information containing 1D and 2D NMR, and MS data for isolated compounds is available free of charge at http:// quimicanova.sbq.org.br as a PDF file.

\section{ACKNOWLEDGEMENTS}

The authors are grateful to Prof. Dr. Norberto P. Lopes and José Carlos Tomaz from Faculdade de Ciências Farmacêuticas de Ribeirão Preto, USP for the ESIMS analysis, Prof. Dr. A. P. do N. Prata of the DBI/UFS for the botanical identification, as well as to CNPq, CAPES, FAPITEC/SE, FINEP, UFPR, UFS and UFAM for financial support and research fellowships.

\section{REFERENCES}

1. Chatrou, L. W.; Pirie, M. D.; Erkens, R. H. J.; Couvreur, T. L. P.; Neubig, K. M.; Abbott, J. R.; Mols, J. B.; Mass, J. W.; Saunders, R. M. K.; Chase, M. W.; Bot. J. Linn. Soc. 2012, 169, 5; Maas, P. J. M.; Kamer, H. M.; Junikka, L.; Mello-Silva, R.; Rainer, H.; Rodriguésia 2001, 52, 61.

2. Moreira, I. C.; Roque, N. F.; Vilegas, W.; Zalewski, C. A.; Lago, J. H. G.; Funasaki, M.; Chem. Biodivers. 2013, 10, 1921.
3. Corrêa, M. P.; Dicionário das plantas úteis do Brasil e das exóticas cultivadas, IBDF: Rio de Janeiro, 1984.

4. Karioti, A.; Hadjipavlou-Litina, D.; Mensah, M. L. K.; Fleischer, T. C.; Skaltsa, H.; J. Agric. Food. Chem. 2004, 52, 8094.

5. Quintans, J. S. S.; Soares, B. M.; Ferraz, R. P. C.; Oliveira, A. C. A.; Silva, T. B.; Menezes, L. R. A.; Sampaio, M. F. C.; Prata, A. P. N.; Moraes, M. O.; Pessoa, C.; Antoniolli, A. R.; Costa, E. V.; Bezerra, D. P.; Planta Med. 2013, 79, 123; Queiroz, J. C.; Antoniolli, A. R.; Quintans-Júnior, L. J.; Brito, R. G.; Barreto, R. S. S.; Costa, E. V.; Silva, T. B.; Prata, A. P. N.; Lucca Jr., W.; Almeida, J. R. G. S.; Lima, J. T.; Quintans, J. S. S.; Sci. World J. 2014, 2014, ID 816450.

6. Silva, D. M.; Costa, E. V.; Nogueira, P. C. L.; Moraes, V. R. S.; Cavalcanti, S. C. H.; Salvador, M. J.; Ribeiro, L. H. G.; Gadelha, F. R.; Barison, A.; Ferreira, A. G.; Quim. Nova 2012, 35, 1570.

7. Maia, J. G. S.; Andrade, E. H. A.; Da Silva, A. C. M.; Oliveira, J.; Carreira, L. M. M.; Araújo, J. S.; Flavour Fragance J. 2005, 20, 474; Moreira, I. C.; Lago, J. H. G.; Young, M. C. M.; Roque, N. F.; J. Braz. Chem. Soc. 2003, 14, 828.

8. Da Silva, M. S.; Tavares, J. F.; Queiroga, K. F.; Agra, M. F.; BarbosaFilho, J. M.; Almeida, J. R. G. S.; Da Silva, S. A. S.; Quim. Nova 2009, 32, 1566; Puvanendran, S.; Wickramasinghe, A.; Karunaratne, D. N.; Carr, G.; Wijesundara, D. S. A.; Andersen, R.; Karunaratne, V.; Pharm. Biol. 2008, 46, 352.

9. López, R.; Cuca, L. E.; Delgado G.; Parasite Immunol. 2009, 31, 623.

10. Castelo-Branco, M. V. S.; Tavares, J. F.; Silva, M. S.; Barbosa Filho, J. M.; Anazetti, M. C.; Frungillo, L.; Haun, M.; Diniz, M. F. F. M.; Melo, P. S.; Rev. Bras. Farmacogn. 2011, 21, 1035.

11. Nishiyama, Y.; Moriyasu, M.; Ichimaru, M.; Iwasa, K.; Kato, A.; Mathenge, S. G.; Mutiso, P. B. C.; Juma, F. D.; J. Nat. Med. 2010, 64, 9.

12. Pontes, W. J. T.; Oliveira, J. C. S.; Câmara, C. A. G.; Gondim Jr., M. G. C.; Oliveira, J. V.; Schwartz, M. O. E.; Quim. Nova 2007, 30, 838.

13. Nguemtchouin, M. M. G.; Ngassoum, M. B.; Ngamo, L. S. T.; Gaudu, X.; Cretin, C.; Crop Prot. 2010, 29, 985.

14. Barbosa, L. T. C.; Vega, M. R. G.; Rev. Virtual Quim. 2017, 9, 1712.

15. Pontes, A. F.; Barbosa, M. R. V.; Maas, P. J. M.; Acta Bot. Bras. 2004, $18,281$.

16. Costa, E. V.; Silva, T. B.; Menezes, L. R. A.; Ribeiro, L. H. G.; Gadelha, F. R.; Carvalho, J. E.; Souza, L. M. B.; Silva, M. A. N.; Siqueira, C. A. T.; Salvador, M. J.; J. Essent. Oil Res. 2013, 25, 179.

17. Silva, T. B.; Menezes, L. R. A.; Sampaio, M. F. C.; Meira, C. S.; Guimarães, E. T.; Soares, M. B. P.; Prata, A. P. N.; Nogueira, P. C. L.; Costa, E. V.; Nat. Prod. Commun. 2013, 8, 403.

18. Nascimento, A. M. D.; Maia, T. D. S.; Soares, T. E. S.; Menezes, L. R. A.; Scher, R.; Costa, E. V.; Cavalcanti, S. C. H.; La Corte, R.; Neotrop. Entomol. 2017, 46, 223. 
19. Costa, E. V.; da Silva, T. B.; Costa, C. O.; Soares, M. B.; Bezerra, D. P.; Nat. Prod. Commun. 2016, 11, 417.

20. Pereira, T. S.; Esquissato, G. N. E.; Costa, E.V.; Nogueira, P. C. L.; Castro-Prado, M. A. A.; Nat. Prod. Res. 2019, doi:10.1080/14786419. 2019.1624956.

21. Costa, E. V.; Dutra, L. M.; Nepel, A.; Barison, A.; Biochem. Syst. Ecol. 2013, 51, 331 .

22. Menezes, L. R. A.; Costa, C. O. D.; Rodrigues, A. C. B. C.; Santo, F. R. E.; Nepel, A.; Dutra, L. M.; Silva, F. M. A.; Soares, M. B. P.; Barison, A.; Costa, E. V.; Bezerra, D. P.; Molecules 2016, 21, 890.

23. Santos, L. S.; Silva, V. R. S.; Menezes, L. R. A. M.; Soares, M. B. P. S.; Costa, E. V.; Bezerra, D. P.; Oxid. Med. Cell. Longevity 2017, 2017, ID 7126872, doi: 10.1155/2017/7126872.

24. Ragasa, C.Y.; Ganzon, J.; Hofileña, J.; Tamboong, B.; Rideout, J. A.; Chem. Pharm. Bull. 2003, 51, 1208.

25. Ahmed, S. A.; Gogal, R. M.; Walsh, J. E.; J. Immunol. Methods 1994 $170,211$.

26. Feliciano, A. S.; Del Corral, J. M. M.; Gordaliza, M.; Castro, M. A.; Phytochemistry 1991, 30, 695.
27. Hieda, T.; Mikami, Y.; Obi, Y.; Kisaki, T.; Agric. Biol. Chem. 1992, 46, 2477.

28. González, A. G.; Fraga, B. M.; Hernández, M. G.; Luis, J. G.; Tetrahedron 1973, 29, 561 .

29. Dos Santos, P. F.; Duarte, M. C.; Bezerra, D. A. C.; Agra, M. de F.; Filho, J. M. B.; Da Silva, M. S.; Tavares, J. F.; Helv. Chim. Acta 2013, 96, 1085

30. Velandia, J. R.; Carvalho, M. G.; Braz-Filho, R.; Quim. Nova 1998, 21, 397.

31. Leboeuf, M.; Cavé, A.; Bhaumik, P. K.; Mukherjee, B.; Mukherjee, R.; Phytochemistry 1982, 21, 2783.

32. Takahashi, J. Á.; Boaventura, M. A. D.; Bayma, J. C.; Oliveira, A. B.; Phytochemistry 1995, 40, 607.

33. Takahashi, J. A.; Vieira, H. S.; Boaventura, M. A. D.; Hanson, J. R.; Hitchcock, P. B.; Oliveira, A. B.; Quim. Nova 2001, 24, 616.

34. Chen, C. Y.; Chang, F. R.; Wu, Y. C.; J. Chin. Chem. Soc. 1997, 44, 313. 